\title{
OLD MELIORATION SYSTEMS: THE INFLUENCE ONTO FUNCTIONING OF GEOECOSYSTEMS OF RIVER VALLEYS IN THE PARSĘTA (NW POLAND)
}

\author{
JózeF SZPIKowSKI ${ }^{1}$, Grażyna SZPIKOWSKA², MONIKA DomaŃSKA² \\ ${ }^{1}$ Institute of Geoecology and Geoinformation, Adam Mickiewicz University in Poznań, Poland \\ ${ }^{2}$ Geoecological Station in Storkowo, Adam Mickiewicz University in Poznań, Storkowo, Poland
}

Manuscript received: February 9, 2015

Revised version: July 29, 2015

\begin{abstract}
SZPiKowski J., SZPikowska G., DomańsKa M., 2015. Old melioration systems: the influence onto functioning of geoecosystems of river valleys in the Parsęta basin (NW Poland). Quaestiones Geographicae 34(3), Bogucki Wydawnictwo Naukowe, Poznań, pp. 129-140, 4 figs, 1 table. DOI 10.1515/quageo-2015-0024, ISSN 0137-477X.

ABstRACT: Meliorations and their specific forms - irrigations - are one of the forms of anthropopressure within geoecosystems. The research studies conducted within the Parsęta basin focused on the sub-irrigation (seepage irrigation) systems formed in the 19th century. Query of archive materials and maps, hydrochemical and phytosociological terrain mapping and laboratory testing of water samples collected were used in the studies. In the study area were found the remains of the thirty old irrigation systems, which together occupy $2 \%$ of the Parsęta basin area. For many years most of them have not fulfilled their primary economic functions. Still, these systems have an impact on the cycle of waters and have become an important factor in increasing the geo- and biodiversity within the postglacial landscape. By expanding a range of wetland riparian areas, they fulfil relevant functions to protect surface waters against the supply of biogenic components. Some of them could be used to enlarge wetlands and floodplains within river valleys.
\end{abstract}

KEYWORDs: meliorations, irrigations, West Pomerania, the Parsęta basin, geoecosystems of river valleys, geo- and biodiversity

Address of the corresponding author: Józef Szpikowski, Institute of Geoecology and Geoinformation, Adam Mickiewicz

University in Poznań, Poland; e-mail: szpiko@amu.edu.pl

\section{Introduction}

The natural environment and its operation has been increasingly dependent upon human activities (Vitousek et al. 1997, Hooke 2000, Jones 2001). Anthropopressure should be considered both at the sustainable use of natural resources and at the undertaking of various kinds of protective measures. Water - being the particularly valuable natural resource - has always been used in different ways by people. People's management in river valleys is an evident example of a conflict between the natural environment and the need to use water as a raw material, source of energy, route of transport, recreation, etc. (Howell 2001, Vörösmarty et al. 2010).

In the postglacial geoecosystem of north-western Poland, anthropopressure onto river valleys appeared early and gradually took on a large scale and varied nature. Within the West Pomerania, such contacts of people's management with river valleys was favoured by its dense hydrographic network, relatively small and manageable rivers as well as sensibly-shaped economic policies in this regard (Szpikowski 2010).

Since mid-18th century within the West Pomerania, a number of extensive melioration works were initiated under the so-called Freder- 
ican colonisation. The most extensive enterprises included: adjustment of the lower Odra River (launched in 1776), adjustment of the Płonia River combined with lowering the water level in Miedwie and Płoń lakes (from 1770), drainage of wetlands located between Kamień Pomorski and Trzebiatów (started in 1775), unsuccessful adjustments of the Łeba River and Łebsko Lake (1777-1783) or lowering the water level of Wielimie and Trzesiecko lakes (1780-1782) (Szultka, Lesiński 2003). This type of activities performed on a large scale on the basis of the royal decrees and governmental regulations were continued in the $19^{\text {th }}$ century and mainly consisted of deepening and straightening of river channels, removing of boulders, tree trunks and sandbars from rivers, strengthening their banks (Florek 1993). It was aimed to facilitate water drainage and flood prevention. The next stage of works took place in the first 20 years of the $20^{\text {th }}$ century and was related to the construction of water power plants at the West Pomeranian rivers.

Apart from these large-scale melioration works, there were numerous local enterprises run by owners of land and forest estates. The specific intensity of these activities occurred starting from the mid-19th century, after the introduction of the following acts by the Prussian authorities: Act on private water management (1843), Act on the State Melioration Fund (1850) and Act on establishment of water companies (1879) (Monsees 2004). The settlement of the principles of organisation and conduct of this type of works and the specification of manners of their state financial support by investors paved the way to establish water companies among land owners. A number of works on the regulation of streams, drainage of wetlands, lowering water levels in smaller lakes were started. Apart from drainages, numerous irrigation projects were also run. Especially two of them were the flagship examples of irrigation in the West Pomerania. The first one refers to the work by Frederick von Sydow who starting from 1820 began the construction of a canal with its length of $22 \mathrm{~km}$ routing waters from the Płociczna River aimed to irrigate meadows and to provide water to fish ponds near the village of Głusko (the Drawska Plain). The second one is by Ernst von Pilsach, who - upon the purchase of estates in Grzmiąca at the Drawskie Lakeland in 1830 - ran large-range melioration works and constructed the irrigation system. In addition, in 1838 he founded a grassland educational centre, the first of its kind in the Kingdom of Prussia at which, among others, methods of management at irrigated meadows were taught (Langerke 1840). The economic effects of the made irrigations were reflected in the growth of noble varieties of grass, vetches, clover and in the increase of livestock. They were widely promoted in specialist publications, studies and at agricultural conferences (Weber 1840, Langerke 1841), which contributed to the establishment of subsequent irrigation systems.

The spatial arrangements of old irrigation systems can be traced back at archival maps (with their remaining elements recognised). So far, no studies have been undertaken in the scope of old irrigation systems aimed at the determination of their current conditions as well as their impact onto the operation of the natural environment within river valleys of the West Pomerania. The results of works in the Parsęta carchment presented in the article fit into the long-term research studies on the functioning of postglacial geoecosystems of the West Pomerania performed by the Geoecological Station of the Adam Mickiewicz University located in Storkowo at the Drawskie Lakeland.

The aim of the research studies on the impact of old irrigation systems onto the geoecosystems of the Parsęta catchment has been as follows:

- recognition of the presence of old irrigation systems within the Parsęta catchment,

- determination of the role of old irrigation systems in the today's functioning of the geoecosystem within the Parsęta catchment.

\section{Study area}

The Parsęta catchment has an area of $3145 \mathrm{~km}^{2}$ and is located in north-western Poland within the boundaries of West Pomeranian Lakeland (Fig. 1). The origin of the Parsęta catchment relief is connected with Pleistocene transgressions and recessions of the Scandinavian ice-sheets. The greatest influence on the contemporary condition of geographical environment was exerted by the Pomeranian Phase - last stage of the Vistulian Glaciation and the Holocene morphogenetic cycle. In the relief of Parsęta catchment is distinguished zones witch diversity of morphology 
and sediments (Karczewski 1989). In the southern part are: zone of the internal moraine - moraine uplands diversified by keme forms and kettle holes, zone of ice-free spaces forms - uplands of keme plateau and zone of melt-out lake basins. In the central and northern parts of the catchment are the morphological levels of the northern Pomeranian sloping surface - mainly flat moraine uplands and small outwashes. The Parsęta River and its tributaries are flowing in the valleys of varying genesis, consisting of melt-out, erosional or pro-glacial valley sections.

A characteristic feature of the Parsęta catchment is a mosaic of land-use pattern, referring to the relief, lithology and hydrological conditions. The Parsęta catchment can be classified as an agricultural-woodland area (according to the Corine Land Cover 2012): arable land $-42 \%$, meadows $-8 \%$, woods $-41 \%$ and buildings $-1 \%$.

\section{Methods}

The following research methods have been applied in the studies:

- analysis of archival materials, including archival topographic maps,

- terrain recognition of the selected positions combined with mapping of the preserved remains of melioration systems,

- hydrochemical mapping,

- phytosociological mapping,

- calculation and visualisation of the results with applied GIS methods.

The German archival topographical maps (Messtischblätter) scaled 1:25000 from 1877 and the 30 s of the 20th century were used in the studies. The georeference of archival images was conducted through the method of field control points to the existing National Geodetic Coordinate Sys-

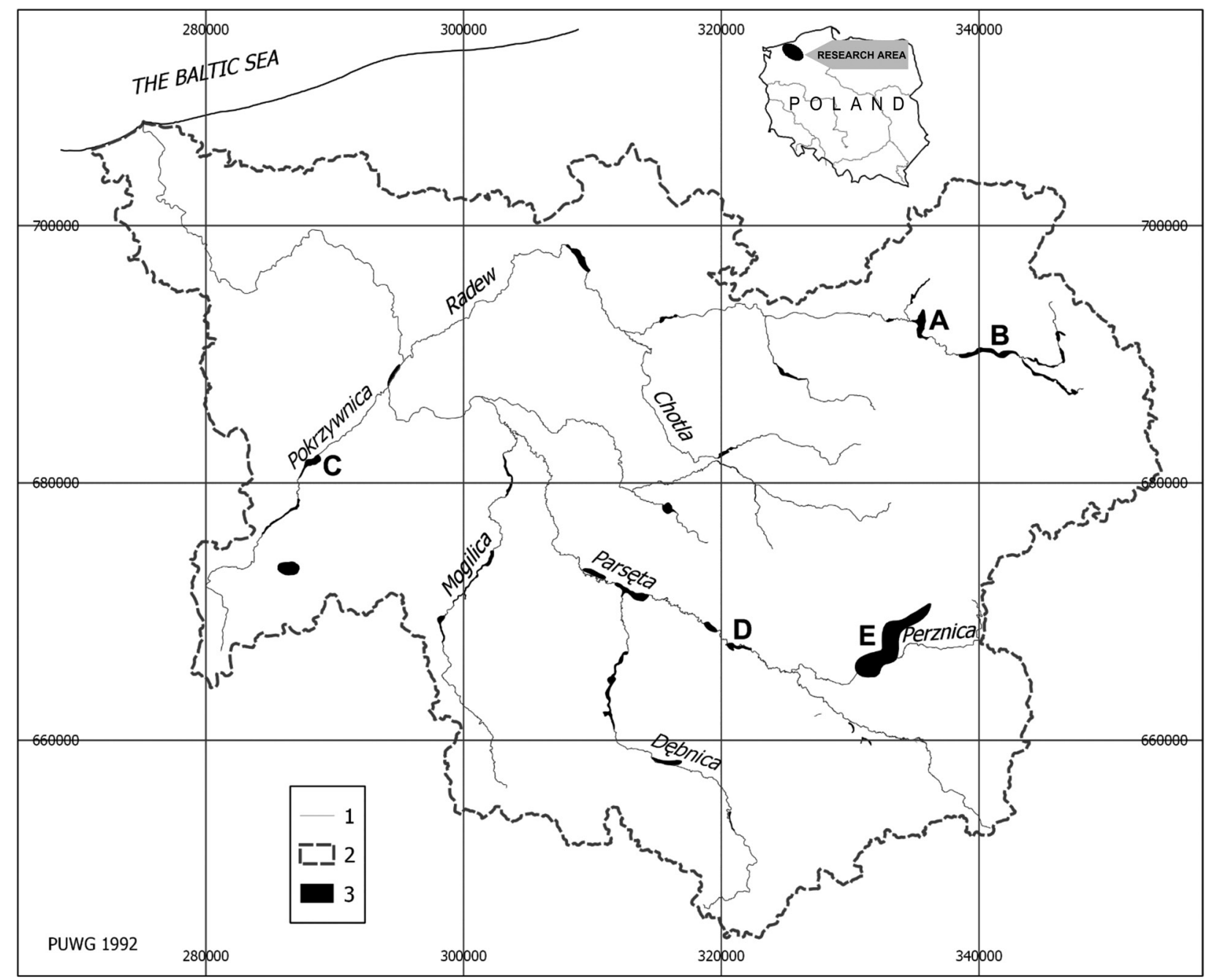

Fig. 1. Location of irrigated areas in the Parsęta catchment.

1 - rivers, 2 - watershed of the Parsęta catchment, 3 - irrigated areas, A-E - research areas. 
tem 1992 (PUWG 1992). QGIS 2.0.1-Dufour software was applied for cartographic calculations and visualisations.

The hydrochemical mapping of irrigation systems within the Parsęta River catchment was conducted in June 2014. Within irrigation ditches with water, in retention reservoirs and in rivers (potentially) supplying irrigation systems, the following were measured (by means of a field meter with a HI9898 multi-parameter probe by Hanna Instruments): temperature, electrical conductivity, $\mathrm{pH}$ and dissolved oxygen content. In the same places water samples were collected to examine their physicochemical properties. Their ionic composition was analyzed at the hydrochemical laboratory at the Geoecological Station of the Adam Mickiewicz University in Storkowo. In total, 22 water samples were analyzed, in which the following was determined $\mathrm{Ca}^{2+}$ concentration (titration - complexometric method), $\mathrm{Mg}^{2+}$ (atomic absorption spectrometry), $\mathrm{Na}^{+}, \mathrm{K}^{+}$ (atomic emission spectrometry), $\mathrm{NH}_{4}^{+}$(spectrophotometric method with Nessler reagent), $\mathrm{HCO}_{3}^{-}$(titration method), $\mathrm{Cl}^{-}, \mathrm{SO}_{4}{ }^{2-}, \mathrm{NO}_{3}^{-}$(ion chromatography), $\mathrm{PO}_{4}^{3-}$ (spectrophotometric method based on molybdate with stannous chloride), ionised $\mathrm{SiO}_{2}$ (spectrophotometric method - reduction to silicon-molybdenum blue). The conducted marking error was specified on the basis ionic balance. The absolute variances of the total of anions and the total of cations in individual samples did not exceed $2.8 \%$ of the total of ionic components and thus were within the acceptable error range.

The phytosociological mapping was performed in June and July 2014 by means of the Braun-Blanquet method. On this grounds plant associations were distinguished on the basis of the Matuszkiewicz's division (Matuszkiewicz 2014).

\section{Results}

\section{Conditions of the selected irrigation objects in the Parsęta catchment}

The irrigation systems built within the Parsęta catchment in the $19^{\text {th }}$ century belong to sub-irrigation system (Molen et al. 2007, Kaca et al. 2011). In technical terms, sub-irrigations are classified to be one of the simplest irrigation networks. Water is gravity-diverted to irrigation ditches, directly after the raising of its level from the river or indirectly from retention reservoirs. When ditches are filled with water, water reaches plant root systems through capillary upward movements. At periods of excess water (e.g. after snow melt, precipitation) the system can fulfil drainage functions which is considered to be the advantage of the system. At the archival maps as well mostly when examined in the field, the individual system components (water damming weirs in rivers and retention reservoirs, main supplying canals and networks of irrigation ditches) can be traced (Fig. 2).

Out of several irrigation systems recognised in the Parsęta catchment, five objects were selected to be examined (marked at Fig. 1 with the letters $\mathrm{A}$ to $\mathrm{E}$ for which the names of their nearby locations were adopted).

The Kepiste irrigation system (Fig. 3A) lies within the peat plains filling an extensive extension in the bottom of the so-called Pomeranian Pro-glacial Valley at the Polanowska Upland. The Radew River waters, upon being dammed by a stone-wooden river bar were directed by means of two main supplying canals along the boundary of the peat plains. It was directed to the left side of the valley over the Radew riverbed through a wooden aqueduct. The supplying canals, at some of their sections being filled with water, have preserved well, then the irrigation ditches are mostly filled with sediments and overgrown. The peat plain, once used as a meadow, has been spontaneously overgrowing with shrubs and trees. In recent times, the initial section of the supply canal was cleaned and made used to provide water to ponds in the newly-established trout farm.

The Kurowo irrigation system (Fig. 3B) extends over a distance of $4 \mathrm{~km}$ within a pro-glacial valley section of the Radew River within the Polanowska Upland. The river waters were dammed of two weirs and directed to the supplying canals extending along the left and right bank of the valley. The supplying canals also seized waters from exudations and springs located in large numbers along the edge of the ice-marginal valley. In this system of irrigation, its supplying canals also directly fulfilled their irrigation functions. Currently the system has not been in operation. Only 


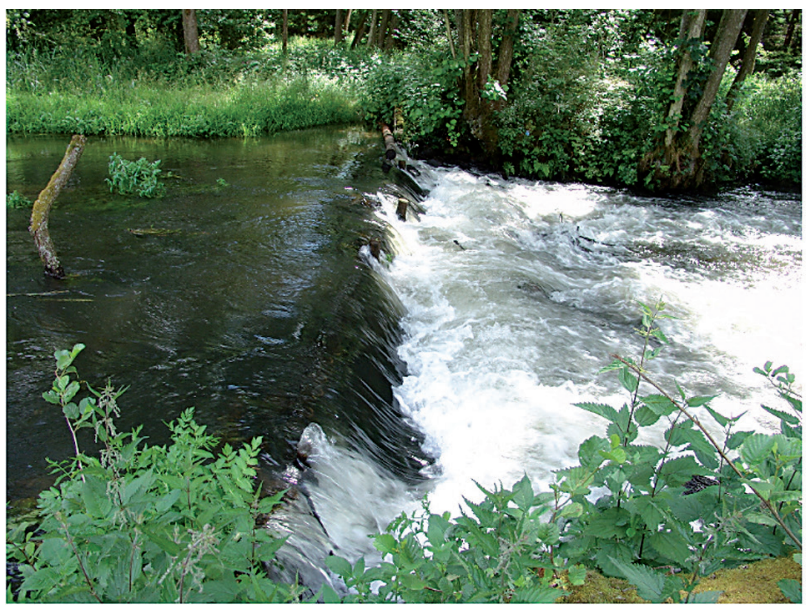

A

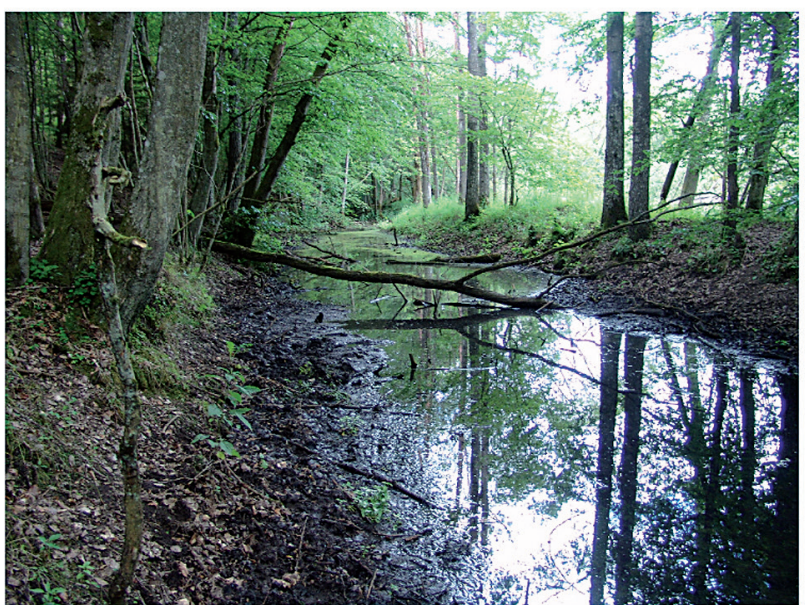

D

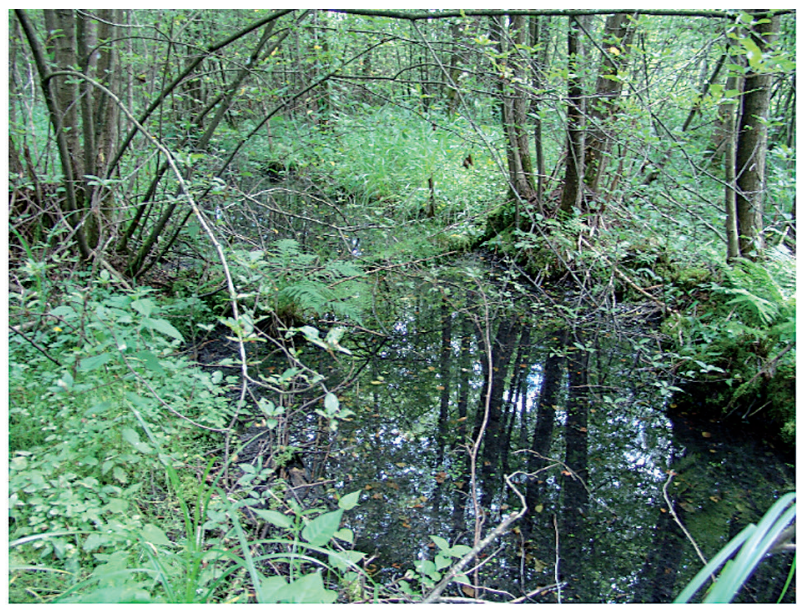

B

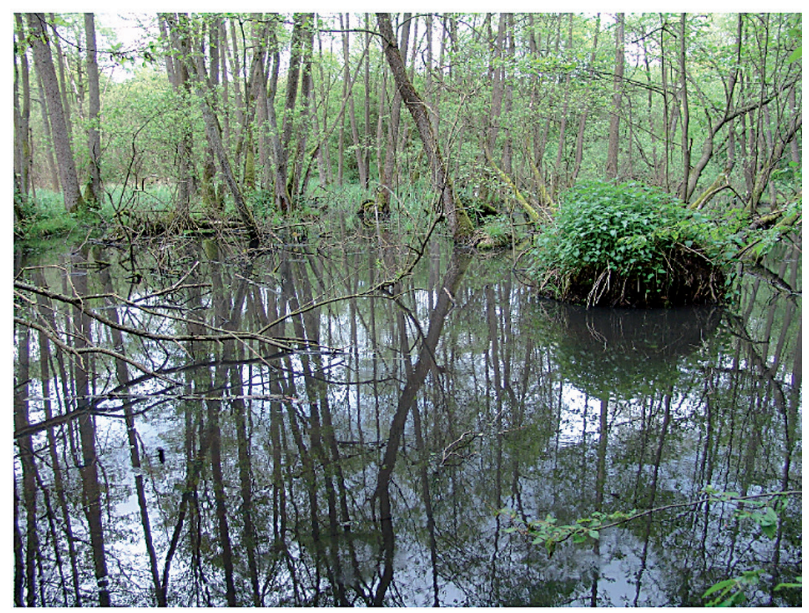

$\mathbf{E}$

Fig. 2. Elements of the old irrigation systems in the Parsęta basin.

A - the damming threshold of the Radew River at the Kępiste object, B - the irrigation ditch at the Kurowo object, D - the main supplying canal at the Krosino object, E - the lagoon in front of a damming weir at the Grzmiąca object, A, B, D, E marking of the research areas from Fig. 1 and Fig. 3.

initial sections of the supplying canals are filled with water. As a result of the lateral erosion of the Radew River and the headwaters erosion at the valley edges, the system of its supplying canals is partially obscured and transformed.

The Rarwino irrigation system (Fig. 3C) located within the Gryficka Plains directed the Pokrzywnica River waters to a supplying canal running at the right side of the valley along a lower slope of the moraine uplands. From the main canal water was directed to a very dense network of irrigation ditches in the valley. The irrigation system has been currently unused, and most of its surface ditches were backfilled or made shallow through mineral-organic sediments. Nowadays the south-western part of the area which used to be irrigated has been forested, while the rest has been used as hay meadows.

The Krosino irrigation system (Fig. 3D) lies in the erosional section of the Parsęta valley within the boundaries of the Drawskie Lakeland. The Parsęta waters were dammed by means of a weir with its stone abutments and directed to a supplying canal running along the left side of the channel. Further, leaving a distance of about $1.5 \mathrm{~km}$ behind, water was provided to main canal which irrigated meadows in the Parsęta valley and in the valley of its tributary. Despite the system not being used, the canal keeps water within a substantial section. During the period of high flows in the Parsęta River it can be supplied directly from the river. 

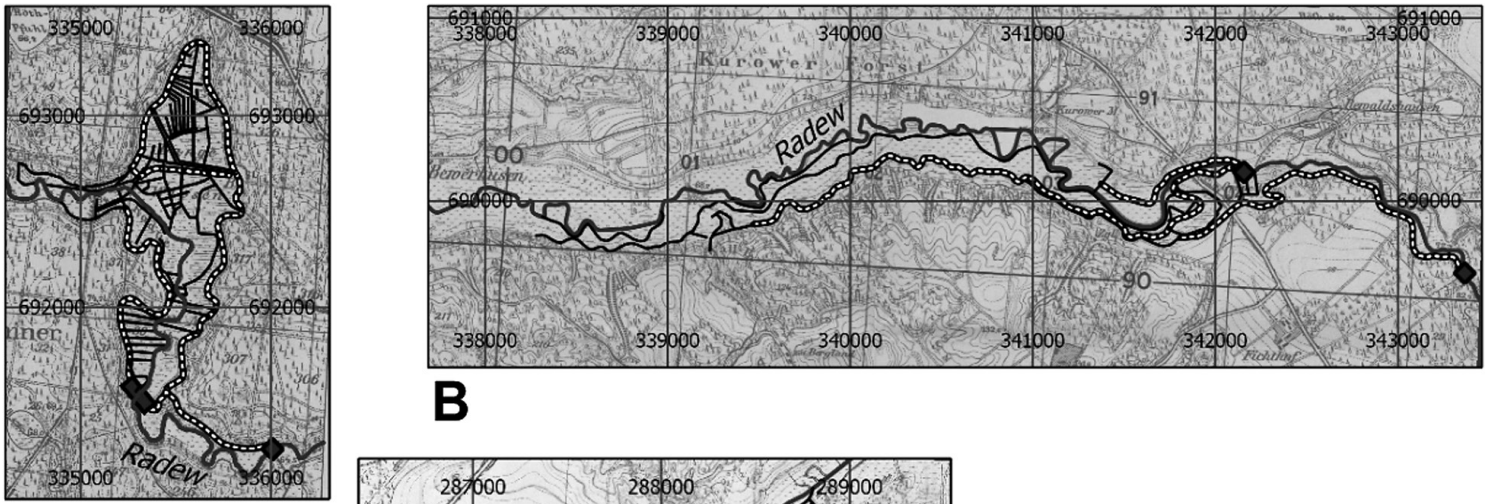

\section{B}
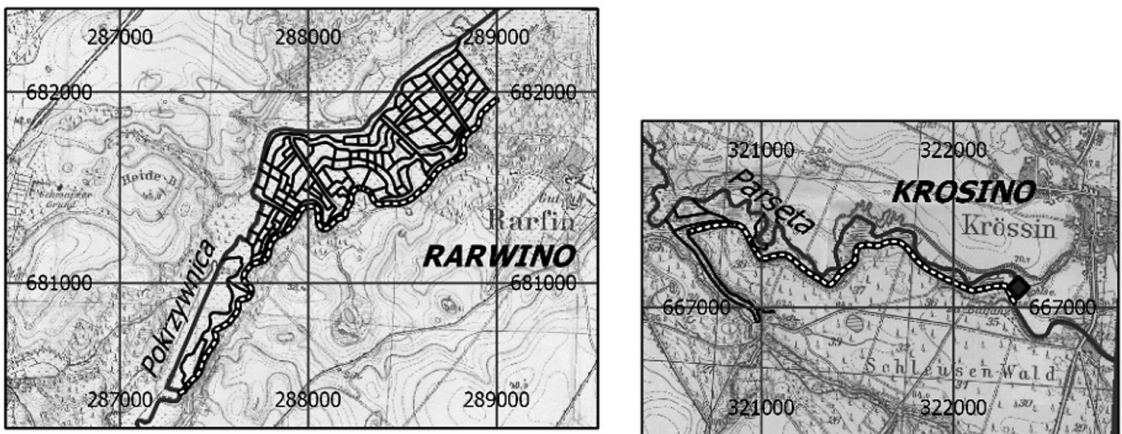

\section{C}

D

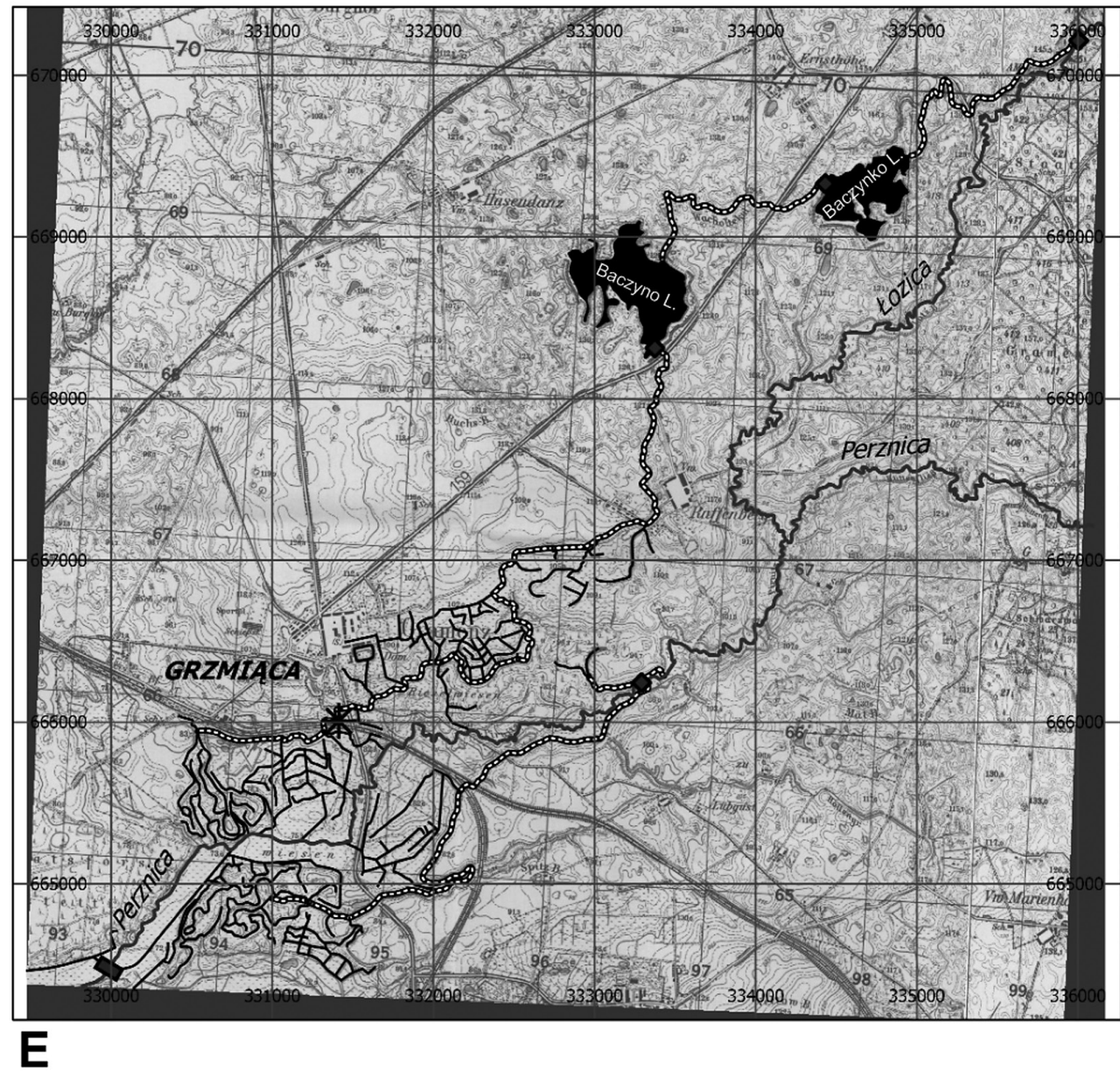

Fig. 3. Irrigation systems at the Parsęta catchment on the basis of the archival topographic maps (30s of the $20^{\text {th }}$ century). 1 - main rivers, 2 - main canals, 3 - retention reservoirs, 4 - irrigation ditches, 5 - main weirs, 6 - aqueducts, 7 - water mill. A-E - location of the research areas from Fig. 1. A - Radew (Keppiste), B - Radew (Kurowo), C - Pokrzywnica (Rarwino), D Parsęta (Krosino), E - Perznica and Łozica (Grzmiąca). 
The Grzmiąca irrigation system (Fig. 3E) located at the Drawskie Lakeland is the most extensive one among the examined objects in the Parsęta catchment. To irrigate meadows located at the right bank of the Perznica valley, waters of its tributary (Łozica) were used. As the Łozica River is a watercourse with its low flows, waters after being dammed by means of a weir were directed to two artificial retention reservoirs currently bearing the name of Baczynko Lake (with its area of $17 \mathrm{ha}$ ) and Baczyno Lake (with its area of $28 \mathrm{ha}$ ). Then by means of a main canal and a network of irrigation ditches, water reached meadows, on its way propelling a water mill. Meadows located at the left side of the valley were irrigated from the Perznica River, after being dammed by means of a concrete weir up to the height of about $2 \mathrm{~m}$. The irrigation system within the area of Grzmiąca has not fulfilled its original economic functions. Currently, meadows, formerly intensively used, also for grazing, have been largely excluded from their agricultural functions. However, in order to preserve Baczyno and Baczynko lakes, a weir at the Łozica River was rebuilt and a small flow of water was provided to these reservoirs.

The detailed information on the examined irrigation objects was presented in Table 1 which summarises the data obtained from the archival maps.

\section{Physical and chemical properties of irrigation water systems}

Water samples within the selected irrigation systems of the Parsęta catchment demonstrate a variation of physic-chemical properties conditioned by different factors such as their sources of supply (groundwater, precipitation, surface waters), soil properties and related bio-geo-chemical conditions. At the same time waters of these irrigation ditches and retention reservoirs connected with the irrigation systems are characterised by their varied chemistry in relation to waters of the rivers which potentially supply them.

The electrical conductivity of waters in drainage ditches is in a broad range of $198-590 \mu \mathrm{S} \mathrm{cm}^{-1}$ (Fig. 4). Its lowest values refer to supplying canals which route waters from the Baczynko and Baczyno retention reservoirs (marked II on the Fig. 4). Its highest value refers to stagnant waters in a ditch within the irrigation system connected with Perznica and may result from a supply of contaminated waters from cultivated fields located nearby (marked I on the Fig 4.). A low level of electrical conductivity is characteristic to waters of the Baczyno and Baczynko retention reservoirs, respectively at 190 and $235 \mu \mathrm{S} \mathrm{cm}^{-1}$. The low conductivity of waters at these reservoirs is caused by that they are supplied with low-mineralised precipitation waters with a limited supply groundwaters. Waters of the Parsęta, Perznica and Radew rivers (marked III on the Fig. 4) are medium-mineralised and have their electrical conductivity, respectively, at 418, 301 and $328 \mu \mathrm{S}$ $\mathrm{cm}^{-1}$.

Most of the examined ditch waters, waters of the two retention reservoirs and waters of the rivers can be classified as low-alkaline (Fig. 4). Water $\mathrm{pH}$ indicating their low-acidic reaction was found just at two measuring points within the Parsęta irrigation system and one - within the Radew irrigation system.

The content of dissolved oxygen in waters of the irrigation ditches varies greatly (Fig. 4) from oxygen deficits in waters at two ditches of the Radew irrigation system (1.05 and $1.25 \mathrm{mg}$ $\mathrm{dm}^{-3}$ ) up to very good oxygenation as in the case of two other measuring points within the same system (13.42 and $\left.14.32 \mathrm{mg} \mathrm{dm}^{-3}\right)$. Waters of the retention reservoirs are characterised by a good level of dissolved oxygen concentration ( $9 \mathrm{mg}$ $\left.\mathrm{dm}^{-3}\right)$. For the purposes of comparison, the con-

Table 1. Parameters of the selected irrigation objects in the Parsęta catchment.

\begin{tabular}{|l|l|c|c|c|c|}
\hline \multicolumn{1}{|c|}{ Object } & \multicolumn{1}{|c|}{ Supply } & $\begin{array}{c}\text { Length of } \\
\text { main canals } \\
{[\mathrm{km}]}\end{array}$ & $\begin{array}{c}\text { Lenght of irriga- } \\
\text { tion ditches } \\
{[\mathrm{km}]}\end{array}$ & $\begin{array}{c}\text { Irrigated areas } \\
{\left[\mathrm{km}^{2}\right]}\end{array}$ & $\begin{array}{c}\text { Density of irri- } \\
\text { gation diches } \\
{\left[\mathrm{km} \mathrm{km}^{-2}\right]}\end{array}$ \\
\hline Kępiste (A) & the Radew River & 6.0 & 14.2 & 77 & 18.4 \\
\hline Kurowo (B) & the Radew River & 6.8 & 9.7 & 100 & 9.7 \\
\hline Rarwino (C) & the Pokrzywnica River & 2.9 & 19.8 & 73 & 27.1 \\
\hline Krosino (D) & the Parsęta River & 2.1 & 38.5 & 14 & 17.9 \\
\hline Grzmiąca (E) & $\begin{array}{l}\text { the Perznica and Łozica rivers, } \\
\text { Baczynko and Baczyno lakes }\end{array}$ & 13.7 & 339 & 11.2 \\
\hline
\end{tabular}



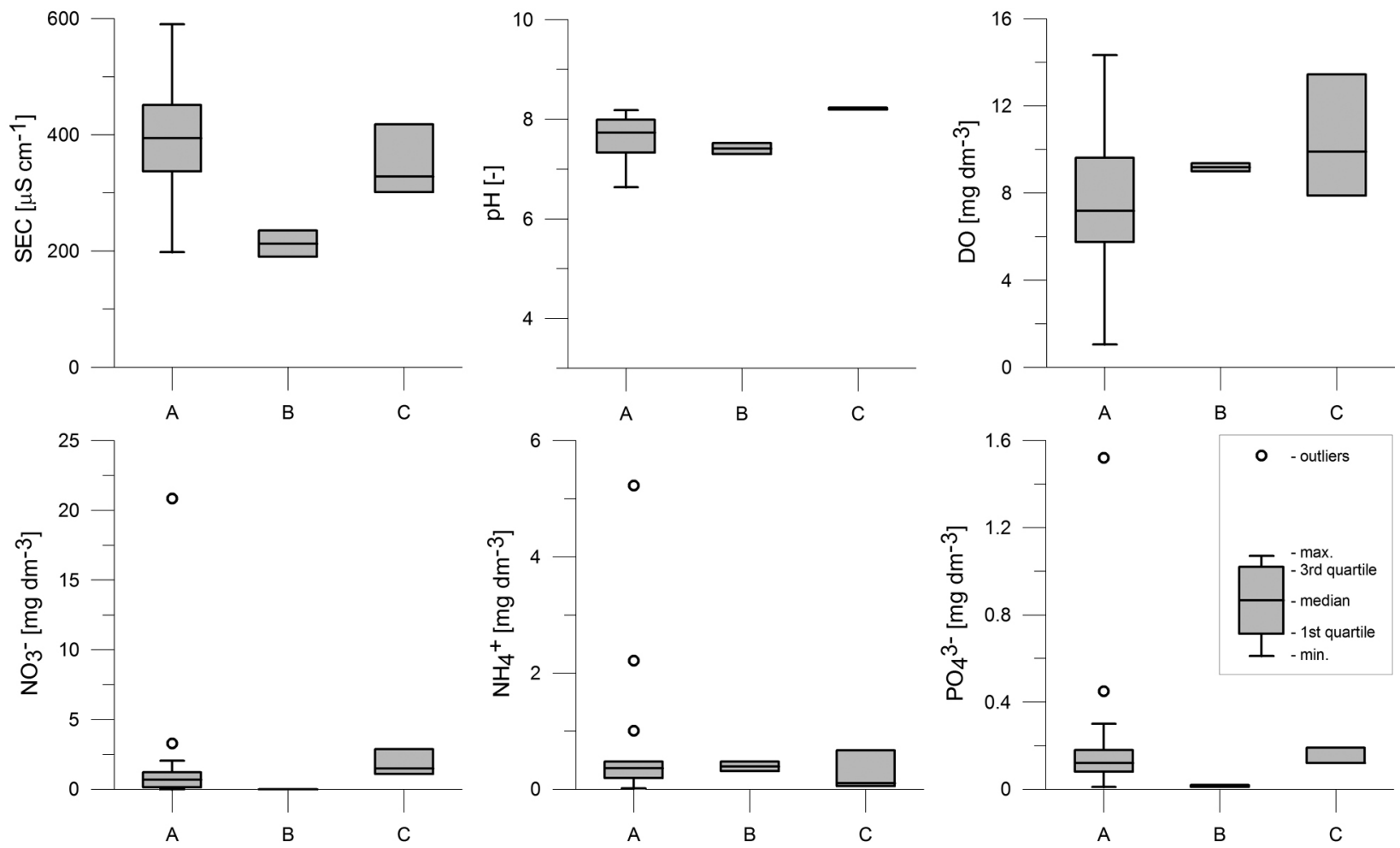

Fig. 4. Variability of the selected physicochemical parameters of waters at the irrigation ditches (A), retention reservoirs (B) and rivers $(\mathrm{C})$ within the old irrigation systems at the Parsęta catchment.

SEC - electrical conductivity, DO - dissolved oxygen.

tent of oxygen in waters of the rivers was as follows: $7.88 \mathrm{mg} \mathrm{dm}^{-3}$ (the Parsęta River), $9.90 \mathrm{mg}$ $\mathrm{dm}^{-3}$ (the Perznica River) and $13.44 \mathrm{mg} \mathrm{dm}^{-3}$ (the Radew River). Generally, the content of dissolved oxygen in waters of the ditches compared with waters of the retention reservoirs and rivers was lower (Fig. 4). It is likely that stagnant or filtering waters with their low speed within the ditches accumulate a large amount of biomass and lose oxygen in the decomposition of organic matter.

On the basis of their ionic composition expressed in eq $\mathrm{dm}^{-3}$, a hydrogeochemical type of the examined waters was specified according to the classification made by Szczukariew-Prikłoński. All waters showed dominant bicarbonate ions (74-96\% of the total of anions) and calcium (68-84\% of the total of cations), which indicates $\mathrm{HCO}_{3}^{-}-\mathrm{Ca}_{2}^{+}$hydrogeochemical type. This type is characteristic to postglacial waters of lakeland areas made up of sediments being abundant with calcium carbonate (Kostrzewski et al. 1994, Mazurek 2008).

The results of marking of biogenic components in waters of the irrigation ditches show a large range of concentration (Fig. 4) related to their local conditions. A level of concentration of nitrate ions, if omitting outliers, were low and ranged within $0.00-2.05 \mathrm{mg} \mathrm{dm}^{-3}\left(0.59 \mathrm{mg} \mathrm{dm}^{-3}\right.$ on average). The highest concentration of nitrates was demonstrated by waters of the ditch being adjacent with cultivated fields within the Perznica-Łozica irrigation system - $20.85 \mathrm{mg} \mathrm{dm}^{-3}$. A level of concentration of ammonium ions in waters at the ditches were at $0.01-0.48 \mathrm{mg} \mathrm{dm}^{-3}$ (0.27 $\mathrm{mg} \mathrm{dm}^{-3}$ on average) and outliers applied to measuring points of the Perznica-Łozica irrigation system $\left(1.00\right.$ and $\left.2.22 \mathrm{mg} \mathrm{dm}^{-3}\right)$ and the Parsęta River $\left(5.23 \mathrm{mg} \mathrm{dm}^{-3}\right)$. Waters at the ditches contained phosphates in amounts of 0.01-0.30 $\mathrm{mg} \mathrm{dm} \mathrm{m}^{-3}\left(0.11 \mathrm{mg} \mathrm{dm}^{-3}\right.$ on average). The highest values (outliers) were recorded within the Perznica-Łozica $\left(1.52 \mathrm{mg} \mathrm{dm}^{-3}\right)$ and Parsęta $(0.55 \mathrm{mg}$ $\mathrm{dm}^{-3}$ ) irrigation systems.

Waters of the retention reservoirs were poor in biogenic components (Fig. 4) and subjected to consumption by living organisms. No nitrate ions were found in waters of these reservoirs and a level of concentration of phosphates did not exceed $0.02 \mathrm{mg} \mathrm{dm}^{-3}$. A level of concentration of ammonium ions was equal to $0.31 \mathrm{mg} \mathrm{dm}^{-3}$ in waters of Baczyno Lake and $0.48 \mathrm{mg} \mathrm{dm}^{-3}$ in waters of Baczynko Lake. 
Compared to waters of the irrigation ditches and retention reservoirs, waters at the rivers showed higher concentrations of nitrate ions, respectively: the Parsęta River $-2.86 \mathrm{mg} \mathrm{dm}^{-3}$, the Perznica River - $1.48 \mathrm{mg} \mathrm{dm}^{-3}$ and the Radew River $-1.08 \mathrm{mg} \mathrm{dm}^{-3}$. The content of ammonium ions $\left(0.10 \mathrm{mg} \mathrm{dm}^{-3}\right.$ for the Parsęta River, $0.67 \mathrm{mg}$ $\mathrm{dm}^{-3}$ for the Perznica River and $0.05 \mathrm{mg} \mathrm{dm}^{-3}$ for the Radew River) in the individual systems was higher or lower in relation to waters of the irrigation ditches. A level of concentration of phosphates in waters at the rivers $\left(0.12-0.19 \mathrm{mg} \mathrm{dm}^{-3}\right)$ was generally higher than the average values in waters of the ditches and retention reservoirs.

\section{Plant communities within irrigation systems}

The phytosociological mapping performed at the selected old irrigation systems of the Parsęta catchment showed that their real vegetation included mostly various associations of Phragmitetea. They are usually characterised by a linear system of vegetation referring to the spatial distribution of their ditches (Lu et al. 2009, Dąbrowska-Prot, Wasiłowska 2012). Communities belonging to the group of Magnocarition are the most commonly found. From within communities belonging to the dynamic circle of vegetation of Ribeso nigri-Alnetum habitats, communities of Caricetum ripariae, with dominant patches of Iridetum pseudacori and Caricetum rostratae were reported (present at all the examined Perznica, Parsęta and Radew catchments). Vegetation of sedge rushes include: Caricetum gracilis and Phalaridetum arundinaceae.

A group of typical rushes is represented by Phragmitetum australis and rushes with dominant Glycerietum maximae. At banks of waters running at a higher speed (fragments of the supplying ditches in the Perznica and Radew valley), species which are characteristic to low or medium-high grassy rushes with dicotyledonous perennials from within Sparganio-Glycerion fluitantis were found. Among them water parsnip Berula erecta is the most widely represented. Scrophularia umbrosa and Veronica beccabunga were also reported.

Within the patches of rush vegetation there are also numerous species being characteristic to meso- and eutrophic wet meadows from $\mathrm{Mo}$ linietalia, among others: Alopecurus pratensis, An- gelica sylvestris, Caltha palustris Cirsium oleraceum, Cirsium palustre, Equisetum palustre, Galium uliginosum, Myosotis palustris, and hydrophilous tall herb fringe communities of Artemisietea as well as Epilobium hirsutum, Galium aparine, Urtica dioica.

From within forest and shrub communities growing at banks of melioration ditches and their immediate neighbourhood, above all, characteristic species from Alnetea glutinosae were found. They are willow thickets with Salix cinerea and Salix pentandra forming the phytocoenoses Salicetum pentandro-cinereae. In the vicinity of ditches supplying the Perznica River there is Ribeso nigri-Alnetum with its characteristic clustered valley structure with Ribes nigrum. In the system of irrigation ditches over the Parsęta River Fraxino-Alnetum (which constitute a link to communities from the class of Alnetea glutinosa (Matuszkiewicz 2014) was specified. According to the Regulation of Minister of the Environment of 9 August 2012 it is a part of natural habitats - 91E0 alluvial forests with Alnus glutinosa and Fraxinus excelsior (Alno-Padion, Alnion incanae, Salicion albae). The so-far studies over the vegetation have focussed on the area of banks and surroundings of supplying and irrigation ditches, then they have not taken into consideration water vegetation from Lemnetea and Potametea. It is likely, therefore, that at active channels periodically (at drained or low waters) silt communities from Bidentetea tripartiti and Isoeto-Nanojuncetea may appear (some communities from these class are a part of habitats of N2000 3270 - Rivers with muddy banks with Chenopodion rubri p.p. and Bidention p.p. vegetetion). The planned further stage of the research studies will be extended to cover the mapping of these groups of plants.

\section{Discussion}

In the studies in irrigation systems, the issue of the recovery of melioration systems and their technical efficiency in conjunction with the restoration of river valleys has been discussed. One of the key arguments in favour of restoring technical efficiency of old irrigation systems is to prevent further mineralisation of peat-muck soils which has currently taken place in conditions of excessive drying of the soil profile (Jurczuk 2005, Oleszczuk et al. 2009). The importance of irriga- 
tion systems to slow down the runoff of water from their catchments has also been highlighted (Szpikowski 2011). As emphasised by Florek (2008), not-thought-over and radical interventions in the system of river channels within the West Pomerania, hydro-technically transformed in the $19^{\text {th }}$ and $20^{\text {th }}$ century (e.g. in the form of re-integration with the old river-beds severed as a result of their regulation and filled with sediments generated at the period when sewage treatment plants were not in operation) could cause danger to the environment.

The research studies conducted at the Parsęta catchment have indicated that abandoned irrigation systems - to a limited extent - can still slow down the runoff by water retention within wetland areas of river valleys. The issue of the restoration of former technical efficiency for old irrigation systems is complex and probably requires individual treatment of particular cases, preferably preceded by their on-spot-examination and reliable expertise. It should be taken into account that most formerly-intensively-used irrigated areas have been deactivated from agricultural production. However, the issue of sub-irrigations and their reconstruction can be introduced into the agri-environmental programmes, especially an element of small retention and in relation to the ecosystem services (Borysiak 2012, Borysiak et al. 2013, 2014). The object in the vicinity of Grzmiąca is an example of the need to maintain efficiency of irrigation systems (at least partially). As indicated by the Regional Water Management materials with no supply of water from the Łozica River going via an artificial canal, it would be impossible to preserve two reservoirs: Baczynko and Baczyno lakes. These reservoirs, perfectly fitting into the moraine landscape of water reservoirs, give the impression of natural lakes and significantly improve the geo- and biodiversity of the natural environment. Technical actions undertaken under the Rural Development Programme for 2007-2013 entitled: "Improvement and development of infrastructure related to the advancement and adaptation of agriculture and forestry through appropriate management of agricultural water resources" should be highlighted in this case. Under the programme, the weir at the Łozica River and the weirs damming water within the reservoirs have been rebuilt with no simultaneous interference in the unnecessary cleaning of its supplying channel.

The old irrigation systems located in the valley parts of the river catchments are an integral part of their riparian areas. Depending on their internal structure, current hydrological and bio-geochemical conditions, they can lead to transformations of the physicochemical properties of waters which supply them. It applies in particular to biogenic components which threaten the eutrophication of surface waters. Biogenic elements may be subject to retention within riparian areas. Today's old irrigation ditches in the Parsęta catchment often remain dry; most frequently water is present within its estuary sections - by rivers, retention reservoirs (surface supply). In other cases, stagnant or low filtering water is the result of underground supply. The presence of water in ditches is conducive to the development of aquaphilous and hygrophilous vegetation which absorbs available biogenic components. Simultaneously, plant communities are an abundant source of biomass being subjected to decomposition which leads to oxygen deficiency. Under such conditions, nitrates can be reduced with the participation of microorganisms which make use of oxygen (taken from non-organic compounds) for their life processes. This process is the primary mechanism of removal of nitrogen from a given geoecosystem (Burt, Haycock 1996, Żurek 2002). Its efficiency has been confirmed by the stationary research studies conducted at the Chwalimski Stream catchment constituting a sub-catchment of the upper Parsęta River (Michalska 2001). Within riparian areas, places with reduction properties (conducive to denitrification, leading to the removal of nitrates) can co-exist with the ones with oxidative properties (determinant to the nitrification of ammonium ions and the retention of phosphates in the form of insoluble compounds) (Zalewski et al. 2001). The concentration of biogenic components in waters at irrigation ditches at the Parsęta catchment in conjunction with the characteristics of waters at rivers indicate that bio-geochemical processes limiting the content of eutrophication-based elements in waters can be run here. In the case of the two water reservoirs, the retention of biogenic elements leads to their use in the life processes of aquatic organisms. 


\section{Conclusion}

1. Irrigation systems in the Parsęta catchment slowed down the outflow of water from the basin and increased its retention. Currently this function has been reduced to the best preserved objects and to the ones being maintained in good technical conditions.

2. A small part of the old irrigation systems have still been used to maintain artificial water reservoirs and utilised for economic needs (provision of water to fish ponds).

3. They - after years of their non-use and non-maintenance - have become important enclaves of geo- and bio-diversity within agrosystems and forest monocultures. They are areas of specific, hygrophilous plant groups (including nature and protectedspecies habitats). They increase landscape values, and some of them - after their adjustment - can fulfil touristic functions.

4. Supply canals and irrigation ditches are a part of riparian areas. They favor the retention of nutrients, protecting river water against eutrophication.

5. In some cases it would be purposeful to undertake limited technical activities in order to stop water in catchment areas with the use of old irrigation systems, e.g. to recover wetlands and floodplains, improvement of plant and animal habitats. This type of actions may be well fitted into the implementation of the Natura 2000 habitat protection programme in the Parsęta basin valleys.

6. Further research studies are recommended to provide more information (using environmental monitoring method) on some selected objects within the old irrigation systems.

\section{Acknowledgements}

The research studies have been financed from the NCN research project no. N N304 274340 entitled: Current state and functioning of the natural environment within the selected areas of West Pomerania under climatic changes and increased anthropopressure.

\section{References}

Borysiak J., 2012. Ecosystem services of extensive wet grasslands. Wielkopolska Region (Poland) case study. Ekonomia i Środowisko 2(42): 136-152.

Borysiak J., Grabowska B., Kubala T., 2013. Conservation of vegetation cover in the Głuszec stream valley in Poznań (Poland) in the agri-environmental program. Roczniki Akademii Rolniczej w Poznaniu 392, Botanika-Steciana 17: 111-130.

Borysiak J., Mazurek M., Zwoliński Zb., 2014. Land cover and ecosystem services changes in agricultural landscapes of the Dębnica River catchment (West Pomerania, Poland). Economics and Environment 4(51): 205-220.

Burt T.P., Haycock N.E., 1996. Linking floodplains to rivers. In: Anderson M.G., Walling D.E., Bates P. (eds), Floodplain Processes. Wiley, New York: 461-492.

Dąbrowska-Prot E., Wasiłowska A., 2012. The role of ecotones in man-disturbed landscape: boundaries between mixed forest and adjacent man-made ecosystems in the Kampinos National Park, Poland. Polish Journal of Ecology 60: 677-698.

Florek W., 1993. Antropopresja a holoceńskie i współczesne procesy fluwialne na obszarze środkowego Pomorza i Pobrzeża (The Holocene and contemporary fluvial processes under anthropopression on the middle part of Pomerania and Baltic Coastal Region). Zeszyty Naukowe PAN 6: 49-60.

Florek W., 2008. Czy renaturyzacja koryt rzek przymorskich może stanowić remedium na skutki ich XIX- i XX-wiecznej regulacji? (Can Pomeranian river channels restoration be a remedy for the consequences of their $19^{\text {th }}$ and 20th century regulation?). Stupskie Prace Geograficzne 5: 75-91.

Hooke R.B., 2000. On the history of humans as geomorphic agents. Geology 28(9): 843-846.

Howell T.A., 2001. Enhancing Water Use Efficiency in Irrigated Agriculture. Agronomy Journal 93(2): 281-289.

Jones D.K.C., 2001. The Evolution of Hillslope Processes. In: Higgit D.L., Lee M.E. (eds), Geomorphological Processes and Landscape Change: Britain in the Last 1000 Years. Blackwell, Oxford: 61-89.

Jurczuk S., 2005. Rola nawodnień podsiąkowych w zwiększaniu retencji wodnej małych dolin rzecznych (The role of subsoil irrigation in increasing water retention in small river valleys). Przeglad Naukowy Inżynieria i Ksztattowanie Środowiska 14(1/31): 140-148.

Kaca E., Drabiński A., Ostrowski K., Pierzgalski E., Szafrański C., 2011. Gospodarowanie wodą w sektorze rolno-żywnościowym i obszarach wiejskich w warunkach nowych wyzwań i ograniczeń (Water management in agriculture, food industry and rural areas in the face of new challenges and limitation). Polish Journal of Agronomy 7: 14-21.

Karczewski A., 1989. Morfogeneza strefy marginalnej fazy pomorskiej na obszarze lobu Parsęty $w$ vistulianie (Pomorze Środkowe) (Morphogenesis of the Pomeranian Phase marginal zone in the Parseta lobe region in the Vistulian (Middle Pomerania). Wyd. Nauk. UAM 44, Poznań: 1-50.

Kostrzewski A., Mazurek M., Zwoliński Z., 1994. Dynamika transportu fluwialnego górnej Parsęty jako odzwierciedlenie funkcjonowania zlewni (Dynamics of fluvial transport of the upper Parseta River as a response of the catchment system). Bogucki Wyd. Nauk., Poznań: 1-165.

Langerke A., 1840. Amtlicher Bericht über die Versammlung deutscher Land- und forstwirthe zu Potsdam in September 
1839 (The official report from the meeting of the German landand forest-owners to Potsdam in September 1839). Berlag von Ludwig Hoid, Berlin: 1-558.

Langerke A., 1841. Landwirthschaftlige Statistik der deutschen Bundesstaaten (Agricultural statistics of the German state). Berlag von George Westermann, Braunschweig: 1-689.

Lu T., Ma K., Fu B., Zhang J., Lu Z., Hudson S., 2009. Diversity and composition of wetland communities along an agricultural drainage ditch density gradient. Polish Journal of Ecology 57: 113-123.

Matuszkiewicz W., 2014. Przewodnik do oznaczania zbiorowisk roślinnych Polski (Guide for the determination of Polish plant communities). Wyd. Nauk. PWN, Warszawa: 1-537.

Mazurek M., 2008. Czynniki kształtujące skład chemiczny wypływów wód podziemnych w południowej części dorzecza Parsęty (Pomorze Zachodnie) (Factors affecting the chemical composition of groundwater outflows in the southern part of the Parsęta drainage basin (West Pomerania). Przeglad Geologiczny 56(2): 131-139.

Michalska G., 2001. Zróżnicowanie właściwości fizykochemicznych wód podziemnych w zlewni Chwalimskiego Potoku (górna Parsęta, Pomorze Zachodnie) (Differentiation of physico-chemical properties of underground water in Chwalimski Potok catchment (upper Parsęta, West Pomerania)). In: Jóźwiak M., Kowalkowski A. (eds), Funkcjonowanie i monitoring geoekosystemów z uwzględnieniem zanieczyszczeń powietrza. Bibl. Monit. Środ., Kielce: 305-320.

Molen W.H., Beltrán J.M., Ochs W.J., 2007. Guidelines and Computer Programs for the Planning and Design of Land Drainage Systems. FAO Irrigation and Drainage Paper 62: 1-229.

Monsees J., 2004. The German Water and Soil Associations - self-governance for small and medium scale water and land resources management. Journal of Applied Irrigation Science 39(1): 5-22.

Oleszczuk R., Chrzanowski S., Brandyk T., Gnatowski T., Szatyłowicz J., 2009. Ocena funkcjonowania systemu odwadniająco-nawadniającego dla zrównoważonego łąkowego wykorzystania gleby torfowo-murszowej (An assessement of the drainage-subirrigation system for sustainable use of peat-moorsch soil). Woda-ŚrodowiskoObszary Wiejskie 9(1/25): 77-86.

Szpikowski J., 2010. Antropogeniczne przeksztatcenia rzeźby zlewni Perznicy w neoholocenie (Pojezierze Drawskie, dorzecze Parsęty) (Anthropogenic relief changes of Perznica catchment in the Neoholocene (Drawskie Lakeland, river Parsęta catchment)). Wyd. Nauk. UAM, Poznań: 1-209.

Szpikowski J., 2011. Geomorphological effects of river valleys anthropogenic transformations in the Perznica catchment during the last 200 years (Drawsko Lakeland, Parsęta River basin). Quaestiones Geographicae 30(1): 105114.

Szultka Z., Lesiński H., 2003. Historia Pomorza. Tom II: do roku 1815. Część 3: Pomorze Zachodnie w latach 1648-1815 (History of Pomerania. Volume II: to 1815. Part 3: West Pomerania in the years 1648-1815). Wyd. Poznańskie, Poznań: 1-1160.

Vitousek P.M., Mooney H.A., Lubchenco J., Melillo J.M., 1997. Human Domination of Earth's Ecosystems. Science 25(277/5325): 494-499.

Vörösmarty C.J., McIntyre P.B., Gessner M.O., Dugeon D., Prusevich A., Green P., Glidden S., Bunn S.E., Sullivan C.A., Reidy Liermann C., Davies P.M., 2010. Global threats to human water security and river biodiversity. Nature 467: 555-561.

Weber F.B., 1840. Handbuch der Staatswirtschaftlichen Statistik und Verwaltungskunde der Preußischen Monarchie (Manual on Statistics of the domestic economy and the knowledge of the administration of the Prussian monarchy). Dei War. Und Comp. in Commission, Breslau: 1-836.

Zalewski M., Bis B., Łapińska M., Puchalski W., 2001. Riparian ecotone as a key factors for stream restoration. Ecohydrology \& Hydrobiology 1: 245-251.

Żurek A., 2002. Azotany w wodach podziemnych (Nitrates in groundwater - an overview). Biuletyn Państwowego Instytutu Geologicznego 400: 115-141. 